\title{
Development of a tissue culture assay system for Campylobacter jejuni cytotoxin and the influence of culture conditions on cytotoxin production
}

\author{
N. MISAWA, T. OHNISHI, K. ITOH* and E. TAKAHASHI*
}

Department of Veterinary Public Health, Faculty of Agriculture, Miyazaki University, Gakuen-Kibanadai, Miyazaki 889-21 and * Department of Veterinary Public Health, Faculty of Agriculture, The University of Tokyo, Bunkyo-ku, Tokyo 113, Japan

\begin{abstract}
Summary. A tissue culture assay system to detect Campylobacter jejuni cytotoxin was developed, and the effect of culture conditions on cytotoxin production was examined. Brothculture filtrates from clinical isolates were used. The expression of cytotoxicity was dependent on the presence of serum in the culture medium. Although the titre of cytotoxin was low, the greatest cytotoxicity was revealed when newborn calf (NCS), adult bovine or goat serum was added to minimum essential medium. Moderate or weak cytotoxicity was observed when fetal calf (FCS), swine or human serum was added, and no cytotoxicity was seen with the addition of horse, rabbit, cat or chicken serum. Furthermore, the cytotoxic titre in serum-free culture (SFC) for Chinese hamster ovary (CHO) cells was higher than that with serum supplementation. CHO cells showed the highest sensitivity in FCS, NCS and SFC assay systems, whereas HeLa, Vero, HEp-2 and Intestine 407 cells were sensitive only in the NCS assay. Brucella broth was excellent for cytotoxin production, but iron supplementation had no effect. Cytotoxic expression in the three assay systems differed between stationary and stirred cultures. Our results on cytotoxin production by reference strains of $C$. jejuni did not agree with the original reports. These findings suggest that several different cytotoxins may be produced by $C$. jejuni, and that the assay system may be important for the expression of cytotoxic activity.
\end{abstract}

\section{Introduction}

Campylobacter jejuni is recognised as a major causative agent of human diarrhoeal disease ${ }^{1-5}$ and numerous attempts have been made to clarify the mechanism by which $C$. jejuni expresses virulence. It has been shown that potential virulence factors include adherence, ${ }^{6-9}$ invasiveness ${ }^{10-11}$ and production of enterotoxin ${ }^{12-24}$ or cytotoxin, ${ }^{25-35}$ but their contribution to pathogenesis has not been clearly demonstrated.

C. jejuni is known to produce at least three toxins-a heat-labile cytotonic enterotoxin, a cytotoxin and a cytolethal distending toxin. ${ }^{36}$ Cytotoxin has been detected in several different strains of $C$. jejuni and has been confirmed to be toxic to Chinese hamster ovary (CHO), Vero, HeLa, HEp-2, Intestine 407 (Int 407) and MRC-5 tissue culture cells. However, the biological, biochemical and genetic characterisation of these holotoxins remains controversial.
Purification and characterisation of this toxin is needed to define its involvement in the pathogenesis of C. jejuni infection but little is known about the effect of culture conditions on toxin production and there is not yet an optimal cell assay system for its detection. In the present study, tissue culture cells were used and appropriate culture conditions were developed for the assay of cytotoxin production by $C$. jejuni.

\section{Materials and methods}

\section{Bacterial strains}

The characteristics of the nine strains of $C$. jejuni used in this study are shown in table I. These strains were isolated from outbreaks of campylobacteriosis. Strains LCDC4483, CCUG7755 and HP5113 were tested in greater detail. The strains were suspended in Nutrient Broth No. 2 (Oxoid) containing dimethylsulphoxide (Sigma) $10 \%$ and stored at $-80^{\circ} \mathrm{C}$ before use. 
Table I. Strains of $C$. jejuni studied

\begin{tabular}{llc}
\hline Strain no. & Received from & Reference no. \\
\hline HP 5113 & T. Itoh & 5 \\
CCUG 7755 & G.-B. Lindblom & 22 \\
LCDC 4483 & H. Lior & 25 \\
LCDC 4182 & & \\
LCDC 3969 & & \\
LCDC 6704 & & \\
ST 23 & A. S. Greeff & 26 \\
ST 116 & & \\
ST 136sp & & \\
\hline
\end{tabular}

\section{Cytotoxin production}

Each strain was grown on horse blood agar for $48 \mathrm{~h}$ at $37^{\circ} \mathrm{C}$ in an atmosphere of $\mathrm{O}_{2} 5 \%, \mathrm{H}_{2} 5 \%, \mathrm{CO}_{2} 10 \%$ and $\mathrm{N}_{2} 80 \%$. A loopful of bacterial growth was inoculated into $20 \mathrm{ml}$ of Brucella Broth (BB; BBL Microbiology Systems, USA) in a flask, and the initial optical density $\left(\mathrm{A}_{550}\right)$ was adjusted to between 0.1 and $0 \cdot 2$. The cultures were incubated at $37^{\circ} \mathrm{C}$ or $42^{\circ} \mathrm{C}$ for 2 or 4 days under stationary or stirred $(100 \mathrm{rpm})$ conditions. After incubation, the number of colony forming units $(\mathrm{cfu}) / \mathrm{ml}$ and $\mathrm{A}_{550}$ were measured. The broth culture was centrifuged at $10000 \mathrm{~g}$ for $30 \mathrm{~min}$ at $4^{\circ} \mathrm{C}$ and filtered through a $0 \cdot 20-\mu \mathrm{m}$ cellulose nitrate membrane (Advantec Toyo Ltd, Tokyo, Japan). The supernate was stored at $4^{\circ} \mathrm{C}$ before testing.

\section{Cell lines for cytotoxin detection}

$\mathrm{CHO}, \mathrm{HeLa}$, Vero and $\mathrm{C} 6$ cells were obtained from the Japanese Cancer Resources Bank (JCRB, Tokyo). Int 407 and HEp-2 cells (ATCC strains) were purchased from Dainippon Pharmaceutical Co., Ltd, Japan. CHO cells were principally used for cell assays when the conditions for cytotoxin detection were being measured. All cells were maintained in 50-ml culture bottles in Eagle's Minimum Essential Medium (MEM; Nissui Pharmaceutical Co., Ltd, Tokyo) supplemented with $200 \mathrm{~mm}$ glutamine, sodium bicarbonate $7.5 \%$ and fetal calf serum (FCS; Gibco Laboratories, USA) $10 \%$.

\section{Cytotoxin assay}

To examine the effect of serum on cytotoxic activity, FCS, newborn calf serum (NCS; Gibco), adult bovine serum (ABS; Nippon Biotest Laboratories, Tokyo), goat (Cosmo-bio Co., Ltd, Tokyo), horse (Flow Laboratories Inc., USA), swine (Cosmo-bio), rabbit (Cosmo-bio), chicken (Flow Laboratories), human (supplied by our laboratory) or cat (supplied by our laboratory) serum were used for the cytotoxic assay with $\mathrm{CHO}$ cells. Trypsinised cells were resuspended in MEM with FCS $10 \%$, and the supernate was aspirated after centrifugation. The cell medium was then replaced with MEM containing $10 \%$ of each serum described above. After washing with the replaced medium, $100 \mu \mathrm{l}$ of the cell suspension were placed in each well of a 96-well microtitration plate at $5 \times 10^{3}$ cells/well, and the cells were allowed to adhere to the bottom of the wells for $1-3 \mathrm{~h}$. Then $100 \mu \mathrm{l}$ of bacteriafree supernate were added to each well, followed by incubation at $37^{\circ} \mathrm{C}$ for $48 \mathrm{~h}$ in air with $\mathrm{CO}_{2} 5 \%$. Cytotoxic effects were assayed at pre-determined times by phase-contrast microscopy, and wells in which $>30 \%$ of the cells showed rounding were considered to show a positive result. $\mathrm{BB}$ alone was used as a negative control.

To examine the effect of serum concentration, FCS or NCS was added to MEM at concentrations ranging from 1 to $30 \%$ for preparation of $\mathrm{CHO}$ cell suspensions and then cytotoxic activity was determined.

ASF 104 medium (Ajinomoto Co., Ltd, Tokyo) as a serum free culture (SFC) was also used for cytotoxicity assay. The $\mathrm{CHO}$ cell suspension was centrifuged and washed with ASF 104 medium, placed in a 96-well microtitration plate and assayed for cytotoxic activity as described above.

Vero, HeLa, Int 407, HEp-2 and C6 cells were used for comparison of sensitivity to cytotoxin in three different media comprising of MEM supplemented with FCS $20 \%$ or NCS $10 \%$ or ASF 104 .

\section{Detection of enterotoxin}

Bacteria-free culture filtrates were also assayed for enterotoxin with a Vibrio cholerae enterotoxin (CT) and Escherichia coli heat-labile enterotoxin (LT) detection kit by reversed passive latex agglutination (RPLA; Denka Seiken Co., Ltd, Tokyo, Japan). Equal volumes of sample and suspension of latex beads coated with rabbit anti-CT antibody were mixed in a 96-well microtitration plate and kept overnight at room temperature. Latex beads coated with normal rabbit IgG were used as a negative control. More than $1-2 \mathrm{ng} / \mathrm{ml}$ of CT was detectable with this assay kit.

\section{Effect of culture conditions on cytotoxin production}

Growth media. C. jejuni HP5113 was grown at $42^{\circ} \mathrm{C}$ for 4 days in five different media: BB, Mueller-Hinton Broth (MHB; Difco), casamino acid yeast extract broth (CYE), ${ }^{20}$ biphasic culture system (BPC ${ }^{25}$ and medium 199 tissue culture medium (M199; Nissui). Furthermore, ferric chloride, ferrous sulphate or IsoVitale X (BBL) was added to BB as an iron source according to the report of McCardell et al. ${ }^{20}$ Serial two-fold dilutions of the test samples in $20 \mathrm{~mm}$ phosphate-buffered saline (PBS), $\mathrm{pH} 7 \cdot 2$, were added to each well, and the titre of cytotoxic activity was recorded as the highest dilution of the sample causing morphological changes in the cells.

Growth conditions. To determine the optimal culture conditions, C. jejuni $\mathrm{HP} 5113$ was grown at $37^{\circ}$ or $42^{\circ} \mathrm{C}$ for 6 days with or without stirring in BB. Bacterial growth was monitored by measuring the $A_{550}$ of the 

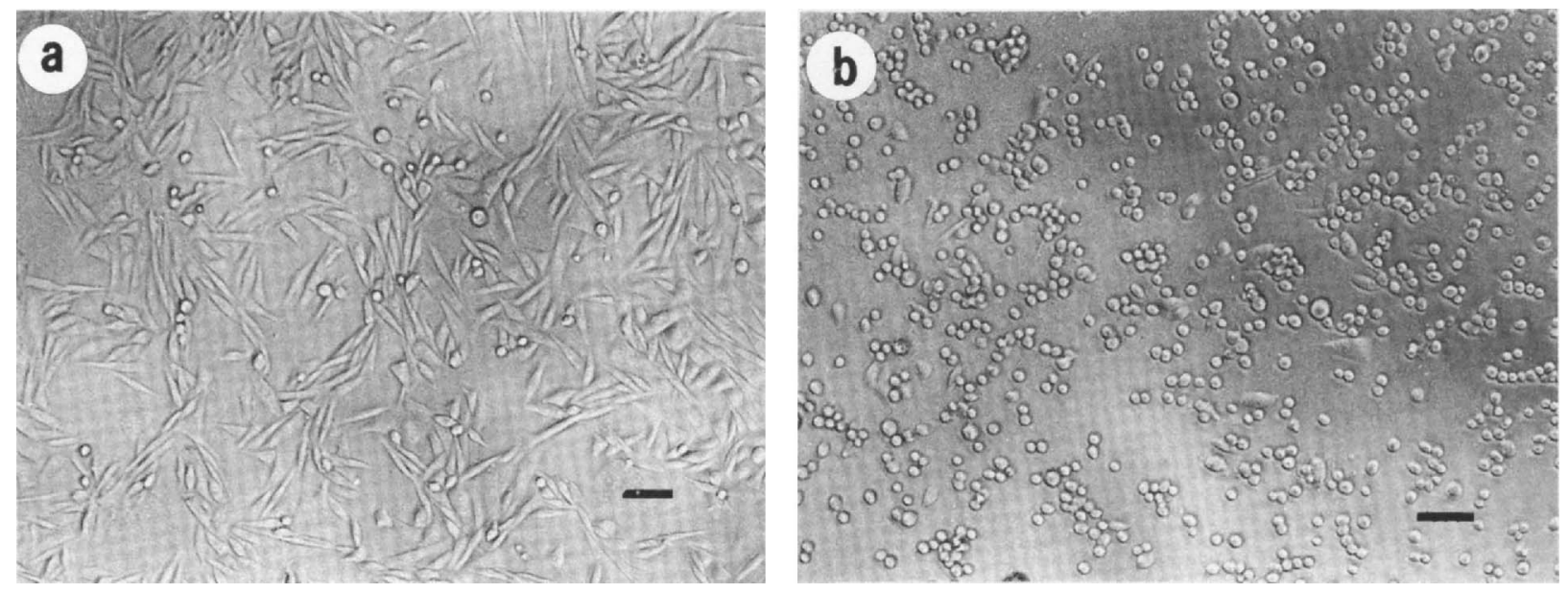

Fig. 1. CHO cells (a) after incubation for $24 \mathrm{~h}$ with BB (control) and (b) after incubation for $24 \mathrm{~h}$ with culture of $C$. jejuni strain HP 5113 . $\mathrm{Bar}=100 \mu \mathrm{m}$.

Table II. Effect of serum from different species on cytotoxic activity

\begin{tabular}{|c|c|c|c|c|c|c|c|c|c|c|}
\hline \multirow[b]{2}{*}{ Test sample } & \multicolumn{10}{|c|}{ Cytotoxic activity with indicated serum addition* } \\
\hline & $\mathrm{FCS} \dagger$ & $\mathrm{NCS} \dagger$ & $\mathrm{ABS} \dagger$ & Goat & Swine & Human & Horse & Rabbit & Cat & Chicken \\
\hline \multicolumn{11}{|l|}{ Culture filtrate of } \\
\hline LCDC 4483 & $+\ddagger$ & +++ & +++ & $++t$ & - & + & - & - & - & - \\
\hline CCUG 7755 & + & $+t+$ & $+t+$ & $+t+$ & ++ & + & - & - & - & - \\
\hline HP 5113 & ++ & $+t+$ & $+t+$ & $++t$ & + & - & - & - & - & - \\
\hline Brucella broth alone & - & - & - & - & - & - & - & - & - & - \\
\hline
\end{tabular}

*See Materials and methods for explanation of abbreviations.

$\dagger$ Each serum was added to tissue culture medium at $10 \%$.

$\ddagger$ Percentage of rounded cells is indicated as: $-, 0-30 \%,+, 31-60 \% ;++, 61-80 \% ;+++, 81-100 \%$.

whole culture and viable cells $(\mathrm{cfu} / \mathrm{ml})$, and then the cytotoxic activity was measured by the three toxin assay systems with the $\mathrm{CHO}$ cell line.

\section{Results}

\section{Effect of cell assay conditions}

Serum from different species. The strongest cytotoxic activity was revealed when NCS, ABS or goat serum was added to MEM (fig. 1 and table II). Moderate or weak toxicity was detected when FCS, swine or human serum was added, and no cytotoxic effect was indicated after addition of other sera. The same data were

Table III. Comparison of cytotoxin titre in three assay systems

\begin{tabular}{lrcc} 
& \multicolumn{3}{c}{ Titre in indicated assay } \\
\cline { 2 - 4 } Strain* no. & SFC & FCS & NCS \\
\hline LCDC 4483 & 8 & 2 & 2 \\
CCUG 7755 & 8 & 2 & 2 \\
HP 5113 & 32 & 2 & 4
\end{tabular}

*Each strain was cultivated in $\mathrm{BB}$ at $42^{\circ} \mathrm{C}$ for 4 days without stirring. obtained even if different lots of serum were used for the assay.

Serum concentration. The cytotoxic effect was dependent on serum concentration. Higher cytotoxic activity was detectable when FCS was added to MEM at $>20 \%$ and the cytotoxic effect was expressed after incubation for $24 \mathrm{~h}$. In contrast to FCS addition, $\mathrm{CHO}$ cell cultures supplemented with NCS $>5 \%$ revealed morphological changes within $24 \mathrm{~h}$ after treatment with the culture filtrate.

Serum-free medium. The cytotoxin titre in the serumfree assay system was higher than that in the serumsupplemented assay system (table III). Notably, the culture filtrate of HP5113 showed a titre of 32 in SFC.

Sensitivity of different cell lines. Comparative studies of the sensitivity of different cell lines were performed with $\mathrm{CHO}$, Vero, HeLa, HEp-2, Int 407 and C6, and the three assay systems. CHO and $\mathrm{C} 6$ were most sensitive cell lines in all the assay systems, whereas Vero, HeLa, HEp-2 and Int 407 cells were sensitive only in the NCS assay system (table IV).

From these data, the most appropriate conditions for detection of cytotoxin were considered to be achieved with $\mathrm{CHO}$ cells as indicator cells and with three assay systems consisting of FCS $20 \%$ or NCS $10 \%$ added to MEM, and ASF 104 medium as a 
Table IV. Comparison of cytotoxic effect against different cell lines

\begin{tabular}{llllllll}
\hline \multirow{2}{*}{ Test sample } & $\begin{array}{l}\text { Cell } \\
\text { assay } \\
\text { system }\end{array}$ & \multicolumn{6}{c}{ Cytotoxic activity against indicated cells } \\
\cline { 3 - 8 } & & CHO & C6 & HeLa & Vero & INT 407 & HEp-2 \\
\hline Culture filtrate of & FCS & $+++\dagger$ & +++ & - & - & - & - \\
HP 5113* & NCS & +++ & +++ & +++ & +++ & +++ & + \\
& SFC & +++ & +++ & + & - & - & - \\
Brucella broth alone & FCS & - & - & - & - & - & - \\
& NCS & - & - & - & - & - & - \\
& SFC & - & - & - & - & - & - \\
\hline
\end{tabular}

${ }^{*} \mathrm{HP} 5113$ strain was cultivated in $\mathrm{BB}$ at $42^{\circ} \mathrm{C}$ for 4 days without stirring.

$\dagger$ Percentage of rounded cells is indicated as:,$- 0-30 \% ;+, 31-60 \% ;++, 61-80 \% ;+++$, $81-100 \%$.

Table V. Cytotoxin production by $C$. jejuni HP $5113^{*}$ in different growth media

\begin{tabular}{|c|c|c|c|c|}
\hline \multirow{2}{*}{$\begin{array}{l}\text { Growth } \\
\text { medium }\end{array}$} & \multirow{2}{*}{$\begin{array}{l}\quad \mathrm{A}_{550} \\
\text { after } \\
\text { cultivation }\end{array}$} & \multicolumn{3}{|c|}{$\begin{array}{l}\text { Titre of indicated } \\
\text { assay system }\end{array}$} \\
\hline & & FCS & NCS & SFC \\
\hline Brucella broth (BB) & 0.96 & 2 & 4 & 32 \\
\hline Casamino yeast extract broth & 0.80 & 2 & 4 & 16 \\
\hline Mueller-Hinton broth & 0.72 & 2 & 2 & 16 \\
\hline Biphasic medium & 0.86 & 2 & 2 & 4 \\
\hline M199 & 0.40 & $<2$ & $<2$ & $<2$ \\
\hline \multicolumn{5}{|l|}{ BB supplemented with } \\
\hline $\mathrm{FeCl}_{3} 0.02 \mu \mathrm{g} / \mathrm{ml}$ & $0 \cdot 91$ & 2 & 4 & 16 \\
\hline $1 \mu \mathrm{g} / \mathrm{ml}$ & 0.98 & 2 & 4 & 16 \\
\hline $\mathrm{FeSO}_{4} 0 \cdot 1 \mu \mathrm{g} / \mathrm{ml}$ & 0.91 & 2 & 4 & 16 \\
\hline $1 \mu \mathrm{g} / \mathrm{ml}$ & 0.91 & 2 & 4 & 16 \\
\hline IsoVitaleX $1 \%$ & 0.91 & $<2$ & $<2$ & 16 \\
\hline
\end{tabular}

*Strain HP 5113 was cultivated at $42^{\circ} \mathrm{C}$ for 4 days without stirring.

A
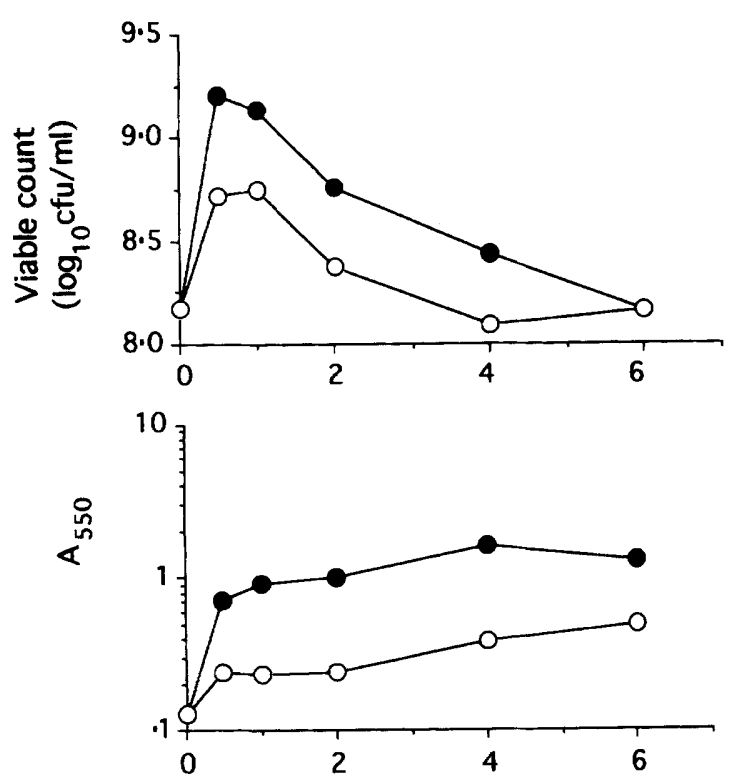

serum-free medium, as it was doubtful whether the same cytotoxin would be detectable in each assay system.

\section{Influence of culture conditions on cytotoxin production}

Effect of growth media. Five media were evaluated for cytotoxin production. The cytotoxin titres of BB and CYE cultures filtrates from the same strain were the same, but the M199 culture filtrate had no cytotoxic effect. MHB and BPC were inferior to BB and CYE for cytotoxin production. Cytotoxic activity was not increased by using BB supplemented with ferric chloride and ferrous sulphate for enterotoxin production as reported by McCardell et al. ${ }^{20} \mathrm{In}$ contrast, cytotoxic activity was depressed by addition of IsoVitale X $1 \%$ without the SFC assay system (table V).

Culture conditions. To determine the optimal culture

B

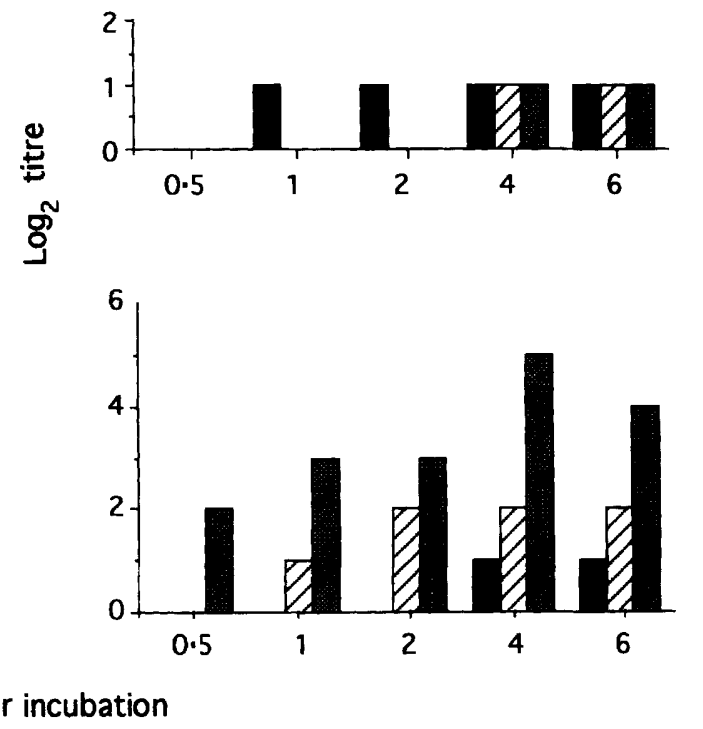

Fig. 2. Time course of bacterial growth (a) and cytotoxic titre (b). C. jejuni strain HP 5113 was cultivated in BB at $42^{\circ} \mathrm{C}$. a, viable counts (upper) and bacterial turbidity (below); 9 , stationary; $\bigcirc$, stirred. b, cytotoxic titre in stirred (upper) and stationary culture (below); $\mathbf{\square}, F C S ; \Xi Z$, NCS; 四, SFC. 
Table VI. Discrepancy in the profile of toxin production between the original reports and the assay systems used in this study

\begin{tabular}{|c|c|c|c|c|c|c|}
\hline \multirow{3}{*}{ Strain* no. } & \multicolumn{6}{|c|}{ Profile of toxin production in } \\
\hline & \multicolumn{2}{|c|}{ original reports ${ }^{25,26}$} & \multicolumn{4}{|c|}{ this experiment } \\
\hline & Enterotoxin & Cytotoxin & RPLA & FCS & NCS & SFC $\dagger$ \\
\hline LCDC 4483 & + & + & - & 2 & 2 & $8+$ \\
\hline LCDC 4182 & + & - & - & 2 & 4 & $16^{\circ}$ \\
\hline LCDC 3969 & - & + & - & 2 & $<2$ & 4 \\
\hline LCDC 6704 & - & - & - & 2 & $<2$ & 32 \\
\hline ST 23 & + & t & - & 2 & 4 & 32 \\
\hline ST 116 & + & - & - & 2 & 4 & 16 \\
\hline ST 136sp & - & - & - & 2 & 4 & 16 \\
\hline CCUG 7755 & + & Unknown & - & 2 & 2 & 8 \\
\hline HP 511 & Unknown & Unknown & - & 2 & 4 & 32 \\
\hline
\end{tabular}

*Each strain was cultivated in $\mathrm{BB}$ at $42^{\circ} \mathrm{C}$ for 2 days with stirring or for 4 days without stirring. $\dagger$ See Materials and methods for explanation of abbreviations.

$\ddagger$ Cytotoxin titre.

conditions, comparative studies were performed with or without stirring at $37^{\circ} \mathrm{C}$ and $42^{\circ} \mathrm{C}$. Both bacterial growth and optical density in the stationary culture were greater than in the stirred culture (fig. 2). The combination of cytotoxic expression in the three assay systems differed between stirred and stationary cultures. Cytotoxic activity in the NCS and SFC assay systems was observed in the stationary culture filtrate at an earlier stage of culture. In contrast, the activity in the FCS assay was detected more easily in the stirred culture filtrate after incubation for $24 \mathrm{~h}$. Culture temperature had no obvious effect on toxic activity.

From these data, we considered that the optimal culture conditions for cytotoxin production were achieved with BB as the growth medium and by culturing the bacteria at $42^{\circ} \mathrm{C}$ for 4 days in a stationary culture.

\section{Cytotoxin and enterotoxin production by Campylobacter isolates}

The results of cytotoxin and CT-like or LT-like toxin detection from $C$. jejuni clinical isolates are summarised in table VI. RPLA assay showed that enterotoxin that was cross-reactive with CT or LT was not produced by any strains. Our data on the cytotoxin produced from reference strains did not agree with the original reports. ${ }^{25,26}$

\section{Discussion}

Cytotoxins have been demonstrated in human and non-human strains of Campylobacter and determined to be toxic to HeLa, Vero, HEp-2, Int 407, MRC-5, and $\mathrm{CHO}$ cell lines. ${ }^{25-35}$ However, it is difficult to determine the characteristics of the cytotoxins, as the procedures used for preparing samples of cytotoxins differ among laboratories. This confusion appears to be attributable either to the presence of several different cytotoxins or to the lack of a reliable assay system for studying cytotoxins of Campylobacter spp. This study demonstrated that the production and detection of cytotoxin was greatly influenced by the culture conditions and assay system employed. Many researchers have adopted a tissue culture system for detection of cytotoxin, and FCS has usually been used for serum supplementation. However, when we used FCS, we were unable to detect cytotoxic activity in Vero, HeLa, HEp-2 or Int 407 cell cultures. In contrast, cytotoxic activity was observed on all cell lines employed when NCS was added to MEM. Furthermore, a high level of cytotoxic activity on CHO cells was observed with the SFC assay system. These findings suggest that the substance amplifying or inhibiting the cytotoxic activity, or both, may be present in serum. Goossens et al., ${ }^{28}$ Mahajan et al.,${ }^{34}$ and Florin et $_{\text {al }}{ }^{35}$ adopted the NCS assay system for cytotoxin detection, but used different media and procedures for cytotoxin production, and it is still not clear whether the same cytotoxin was detected by each researcher. McCardell et al. ${ }^{29}$ reported that heat-stable cytotoxin was detected when the concentration of FCS in the tissue culture medium was reduced to $0.7 \%$, and that the cytotoxicity was inactivated by normal rabbit serum. In our experiments, the cytotoxicity was also inactivated when normal rabbit, horse, cat or chicken serum was added to MEM for $\mathrm{CHO}$ cell culture, but we failed to detect any cytotoxicity when FCS $1 \%$ was added.

There is a possibility that several different cytotoxins are produced by $C$. jejuni. In the present study, different cytotoxins may have been detected in each of the three assay systems, because it is difficult to consider that these differences in cytotoxic expression are attributable to the sensitivity of the cells to the cytotoxin in each assay system. The combination of cytotoxin expression in the three assay systems varied 
according to bacterial culture conditions, i.e., with or without stirring. The characteristics of crude cytotoxin described in previous reports differed with respect to heat stability, ${ }^{27,29}$ molecular mass ${ }^{29,31,34}$ and cytotoxicity against cultured cells. ${ }^{25,27,28,35}$ Cytotoxin production by the reference strains in this study did not correspond to that in the original reports. ${ }^{25,26}$ It is possible that our assay systems for $C$. jejuni cytotoxin might detect a different type of cytotoxin from the original reports.

The best conditions for cytotoxin production in the NCS and SFC assay systems were growth for 4 days in $\mathrm{BB}$ at $37^{\circ} \mathrm{C}$ or $42^{\circ} \mathrm{C}$ without stirring. In contrast, stirred cultures were better than the stationary culture for detection in the FCS assay system. Further study is required to clarify whether cytotoxic activity in the three assay systems is an expression of different toxins. The characteristics and the role of these factors in pathogenesis of $C$. jejuni infection remain to be determined.

An enterotoxin produced by $C$. jejuni has been detected by three methods - cytotonic effect on $\mathrm{CHO}$ cells, ${ }^{12,13,15,16,19,21,22,26,35}$ the $\mathrm{GM}_{1}$ ganglioside en- zyme-linked immunosorbent assay ${ }^{14,16-18,20,21,23,24}$ or neutralisation test based upon immunologic crossreactivity with anti-CT or anti-LT antibody. ${ }^{12.16 .19}$ In this study, we attempted to detect the enterotoxin by RPLA with anti-CT antibody. However, we were unable to detect CT-like enterotoxin despite the fact that the reference strains had originally been shown to produce the enterotoxin by a CHO assay. One explanation for these discrepant results was that the culture condition examined in this study was not suitable for enterotoxin production. Johnson and Lior reported that the response of $\mathrm{CHO}$ cells to a cytolethal distending toxin produced by Campylobacter strains was possibly misinterpreted as the heat-labile enterotoxin. ${ }^{36}$ Further study is required to resolve these discrepancies, as several researchers have been unable to find enterotoxin production by Campylobacter strains. $^{37-39}$

We thank Drs H. Lior (Tunney's Pasture, Canada), G.-B. Lindblom (University of Goteborg, Sweden), A. S. Greeff (Medical University of Southern Africa, South Africa) and T. Itoh (Tokyo Metropolitan Research Laboratory of Public Health, Japan) for kindly supplying the bacterial strains used in this work.

\section{References}

1. Skirrow MB. Campylobacter enteritis: a "new" disease. $B M J$ 1977; 2: 9-11.

2. Butzler JP, Skirrow MB. Campylobacter enteritis. Clin Gastroenterol $1979 ; 8$ : 737-765.

3. Blaser MJ, Berkowitz ID, LaForce FM, Cravens J, Reller LB, Wang W-LL. Campylobacter enteritis: clinical and epidemiologic features. Ann Intern Med 1979; 91: 179-185.

4. Guerrant RL, Lahita RG, Winn WC, Roberts RB. Campylobacteriosis in man: pathogenic mechanisms and review of 91 bloodstream infections. Am J Med 1978; 65: 584-592.

5. Saito K, Shingaki M, Takahashi $\mathbf{M}$ et al. The serotype distribution of Campylobacter jejuni strains among gastroenteritis in hospitals over a 7-year period in Tokyo. $J$ Jpn Assoc Infect Dis 1990; 64: 787-793 (in Japanese).

6. Cinco M, Banfi E, Ruaro E, Crevatin D, Laux DC. Evidence for L-fucose (6-deoxy-L-galactopyranose)-mediated adherence of Campylobacter spp. to epithelial cells. FEMS Microbiol Lett 1984; 21 : 347-351.

7. Newell DG, McBride H, Dolby JM. Investigations on the role of flagella in the colonization of infant mice with Campylobacter jejuni and attachment of Campylobacter jejuni to human epithelial cell lines. J Hyg 1985; 95 : 217-227.

8. Lee A, O'Rourke JL, Barrington PJ, Trust TJ. Mucus colonization as a determinant of pathogenicity in intestinal infection by Campylobacter jejuni: a mouse cecal model. Infect Immun 1986; 51: 536-546.

9. McSweegan E, Walker RI. Identification and characterization of two Campylobacter jejuni: adhesins for cellular and mucous substrates. Infect Immun 1986; 53: 141-148.

10. Konkel ME, Corwin MD, Joens LA, Cieplak W. Factors that influence the interaction of Campylobacter jejuni with cultured mammalian cells. J Med Microbiol 1992; 37: 30-37.

11. Everest PH, Goossens H, Butzler JP et al. Differentiated Caco2 cells as a model for enteric invasion by Campylobacter jejuni and C. coli. J Med Microbiol 1992; 37: 319-325.

12. Ruiz-Palacios GM, Torres J, Torres NI, Escamilla E, RuizPalacios BR, Tamayo J. Cholera-like enterotoxin produced by Campylobacter jejuni. Characterisation and clinical significance. Lancet 1983; 2 : 250-253.

13. McCardell BA, Lee EC, Madden JM. Campylobacter jejuni and Campylobacter coli production of a cytotonic toxin immunologically similar to cholera-toxin. J Food Prot 1984; 47: 943-949.

14. McCardell BA, Madden JM, Lee EC. Production of choleralike toxin by Campylobacter jejuni/coli. Lancet 1984; 1 : 448-449.

15. Johnson WM, Lior H. Toxins produced by Campylobacter jejuni and Campylobacter coli. Lancet 1984; 1: 229-230.

16. Klipstein FA, Engert RF. Properties of crude Campylobacter jejuni heat-labile enterotoxin. Infect Immun 1984; 45: 314-319.

17. Klipstein FA, Engert RF. Purification of Campylobacter jejuni enterotoxin. Lancet 1984; 1: 1123-1124.

18. Klipstein FA, Engert RF. Immunological relationship of the B subunits of Campylobacter jejuni and Escherichia coli heatlabile enterotoxins. Infect Immun 1985; 48: 629-633.

19. Goossens H, Butzler JP, Takeda Y. Demonstration of choleralike entero-toxin production by Campylobacter jejuni. FEMS Microbiol Lett 1985; 29: 73-76.

20. McCardell BA, Madden JM, Stanfield JT. Effect of iron concentration on toxin production in Campylobacter jejuni and Campylobacter coli. Can J Microbiol 1986; 32: 395-401.

21. Lindblom GB, Kaijser B, Sjögren E. Enterotoxin production and serogroups of Campylobacter jejuni and Campylobacter coli from patients with diarrhea and from healthy laying hens. J Clin Microbiol 1989; 27: 1272-1276.

22. Lindblom GB, Cervantes LE, Sjögren E, Kaijser B, RuizPalacios GM. Adherence, enterotoxigenicity, invasiveness and serogroups in Campylobacter jejuni and Campylobacter coli strains from adult humans with acute enterocolitis. APMIS 1990; 98: 179-184.

23. Daikoku T, Suzuki S, Oka S, Takama K. Profiles of enterotoxin and cytotoxin production in Campylobacter jejuni and $C$. coli. FEMS Microbiol Lett 1989; 58: 33-36.

24. Daikoku T, Kawaguchi M, Takama K, Suzuki S. Partial purification and characterization of the enterotoxin produced by Campylobacter jejuni. Infect Immun 1990; 58: 2414-2419.

25. Johnson WM, Lior H. Cytotoxic and cytotonic factors produced by Campylobacter jejuni, Campylobacter coli, and Campylobacter laridis. J Clin Microbiol 1986; 24: 275-281.

26. Bok HE, Greeff AS, Crewe-Brown HH. Incidence of toxigenic 
Campylobacter strains in South Africa. J Clin Microbiol 1991; 29: 1262-1264.

27. Yeen WP, Puthucheary SD, Pang T. Demonstration of a cytotoxin from Campylobacter jejuni. J Clin Pathol 1983; 36: 1237-1240.

28. Goossens H, Rummens E, Cadranel S, Butzler JP, Takeda Y. Cytotoxic activity on Chinese hamster ovary cells in culture filtrates of Campylobacter jejuni/coli. Lancet 1985; 2: 511.

29. McCardell BA, Madden JM, Stanfield JT. Production of cytotoxins by Campylobacter. Lancet 1986; 1: 1031.

30. Guerrant RL, Wanke CA, Pennie RA, Barrett LJ, Lima AA O'Brien AD. Production of a unique cytotoxin by Campylobacter jejuni. Infect Immun 1987; 55: 2526-2530.

31. Pang T, Wong PY, Puthucheary SD, Sihotang K, Chang WK. In-vitro and in-vivo studies of a cytotoxin from Campylobacter jejuni. J Med Microbiol 1987; 23 : 193-198.

32. Akhtar SQ, Huq F. Effect of Campylobacter jejuni extracts and culture supernatants on cell culture. J Trop Med Hyg 1989; 92: $80-85$.

33. Moore MA, Blaser MJ, Perez-Perez GI, O'Brien AD. Production of a Shiga-like cytotoxin by Campylobacter. Microb Pathog 1988; 4 : 455-462.

34. Mahajan S, Rodgers FG. Isolation, characterization, and host- cell-binding properties of a cytotoxin from Campylobacter jejuni. J Clin Microbiol 1990; 28: 1314-1320.

35. Florin I, Antillon F. Production of enterotoxin and cytotoxin in Campylobacter jejuni strains isolated in Costa Rica. $J$ Med Microbiol 1992; 37: 22-29.

36. Johnson WM, Lior H. A new heat-labile cytolethal distending toxin (CLDT) produced by Campylobacter spp. Microb Pathog 1988; 4: 115-126.

37. Wadstrom T, Baloda SB, Krovacek K, Faris A, Bengtson S, Walder M. Swedish isolates of Campylobacter jejuni/coli do not produce cytotonic or cytotoxic enterotoxins. Lancet $1983 ; 2: 911$.

38. Perez-Perez GI, Taylor DN, Echeverria PD, Blaser MJ. Lack of evidence of enterotoxin involvement in pathogenesis of Campylobacter diarrhea. In: Nachamkin I, Blaser MJ, Tompkins LS (eds) Campylobacter jejuni: current status and future trends. Washington, D.C., American Society for Microbiology. 1992: 184-192.

39. Konkel ME, Lobet Y, Cieplak W. Examination of multiple isolates of Campylobacter jejuni for evidence of cholera-like activity. In: Nachamkin I, Blaser MJ, Tompkins LS (eds) Campylobacter jejuni: current status and future trends. Washington, D.C., American Society for Microbiology. 1992: 193-198. 